\title{
POWDER FLOW CRITERIA FOR DESIGN OF VERTICAL SILO WALLS
}

\section{JOSÉ P. LOPES NETO ${ }^{1}$, JOSÉ W. B. DO NASCIMENTO ${ }^{2}$, RAFAEL C. SILVA ${ }^{3}$, CARLOS A. DA COSTA ${ }^{3}$}

\begin{abstract}
For design of vertical silos walls involving the storage of bulk solids to be safe and reliable, it is important knowing the largest possible number of variables such as: flow properties, silo geometry and pattern of flow desired. In order to validate the theories of flow prediction and design of conical hoppers, the flow properties of two bulk solids were determined, the theories of Jenike's flowability and Enstad and Walker for hopper design were analyzed and the results were compared with those experimentally obtained in a reduced model of a semicircular-section silo. Results show that Enstad theory for the hopper design is adequate to occur mass flow inside the silo, and for the sizing of the discharge outlet, the Walker's theory was closer to the appropriate than Jenike’s theory, which was higher around 100\% than the experimental hopper outlet.
\end{abstract}

KEYWORDS: discharge outlet, reduced models, flowability.

\section{CRITÉRIOS DE FLUXO DE PRODUTOS PULVERULENTOS PARA O PROJETO DE SILOS VERTICAIS}

RESUMO: Para que um projeto de silos verticais para armazenagem de produtos sólidos seja seguro e confiável, é importante que um maior número possível de variáveis, como propriedades de fluxo, geometria do silo e tipo de fluxo, sejam definido. No intuito de validar as teorias de previsão de fluxo e dimensionamento de tremonhas cônicas, foram determinadas as propriedades de fluxo de dois produtos armazenáveis, testadas as teorias de fluabilidade de Jenike e de dimensionamento de tremonhas propostas por Enstad e Walker, sendo os resultados comparados com aqueles obtidos experimentalmente em um silo em modelo reduzido de seção semicircular. Os resultados encontrados demonstram que a teoria de Enstad é a mais adequada para promover o fluxo de massa no interior do silo, enquanto a teoria de Walker apresentou valores de orifício de descarga mais próximos dos usados experimentalmente para obter fluxo, ficando os resultados obtidos pelo método de Jenike até $100 \%$ acima do testado experimentalmente.

PALAVRAS-CHAVE: orifício de descarga, modelo reduzido, fluabilidade.

\section{INTRODUCTION}

With the advance in the agricultural industry, the use of silos has become indispensable in order to maintain the products quality such as powders, grains, seeds and derivatives. The silos have the advantage of being able to store large amount in reduced horizontal space, and can control the stock in order to choose the best time for commercialization.

The bulk solid storage in silos is considered a very viable solution due to the economy of space, labor and transportation costs, as well as the possibility of preservation of the ensiled product (CALIL JUNIOR \& CHEUNG, 2007). PALMA \& CALIL JUNIOR (2008) cite that to design a silo with safety, economy and efficiency, it is necessary that the designer knows the maximum pressure possible acting on the silo walls during its operational life.

\footnotetext{
${ }^{1}$ Associate Professor, Department of Agricultural Engineering, Federal University of Campina Grande, Campina Grande, Paraíba, Brazil, lopesneto@deag.ufcg.edu.br.

${ }^{2}$ Associate Professor, Department of Agricultural Engineering, Federal University of Campina Grande, Campina Grande, Paraíba, Brazil.

${ }^{3}$ Agricultural Engineer. Master Student of Agricultural Engineering, Department of Agricultural Engineering, Federal University of Campina Grande, Campina Grande, Paraíba, Brazil.

Recebido pelo Conselho Editorial em: 20-11-2012
}

Aprovado pelo Conselho Editorial em: 23-1-2013 
According to LOPES NETO et al. (2009b), one of the main obstacles faced by industries that process powder and bulk solids is the formation of cohesive arches able to partially or completely restrict discharge, which occurrence is intrinsically related to the geometry of silos and hoppers, to the physical properties and flow of bulk solids and environmental conditions such as pressure, temperature and relative humidity.

CANNAVACCIUOLO et al. (2009) reported that powders with high cohesion may be difficult to flow due to the influence of gas-solid and solid-solid dynamic interactions. A proposal to reduce this condition is the aeration of the product during discharge in order to produce pressure gradients near the discharge orifice.

A major contribution in this research field was given by JENIKE (1964), who developed the translational shear tester, known as Jenike Shear Tester, used to determine the internal friction angle, wall friction angle, bulk density, flow function and rate, and to define the flow pattern in mass and funnel silos, important parameters for the design of vertical silos.

SCHULZE (2008) reports that the Jenike Shear Tester uses a set of cells to reproduce shear in samples of storable products, making it possible to draw stress circles (Mohr circles), which graphically represent the stress status in a portion of the stored product, being possible to determine the consolidation stress $\left(\sigma_{\mathrm{M}}\right)$, unconfined stress $\left(\mathrm{f}_{\mathrm{C}}\right)$ and the internal friction angle $(\varnothing)$ of storable products (LOPES NETO et al., 2007).

JULIANO et al. (2006) reported that the flow properties are responsible for determining the type of flow in silos, hoppers and conveyors, which could maximize operations such and discharges; bin transfers, dosage and packaging, and avoid uncertainties regarding the pattern of flow and discharge obstructions.

With the aim of understanding the flow criteria, its alterations and intervening variables, this study aimed to determine the flow properties of food powders, the flow pattern prediction and the validation of theories by digital images obtained in a reduced model.

\section{MATERIAL AND METHODS}

Since the aim of this research was to study storage in silos, two powder material commonly used in the agricultural area, ground corn and soybean meal, were selected. The particle size determination of the analyzed products was performed by classical methods of sample sieving using $500 \mathrm{~g}$ of each sample, while the moisture content was determined by gravimetric method with drying in stove of $50 \mathrm{~g}$ of each product at $105^{\circ} \mathrm{C}$ for $24 \mathrm{~h}$.

The flow properties were determined using the Translational Shear Tester based in Jenike Shear Cell (Figure 1) according to methodology described by BMHB (1985). Series 100 N (70; 50 and $35 \mathrm{~N}), 70 \mathrm{~N}(50$; 35 and $20 \mathrm{~N}$ ) and $50 \mathrm{~N}$ (35; 20 and $10 \mathrm{~N}$ ) were used as pre-shear and shear loads.



FIGURE 1. Jenike Shear Cell.

To determine the wall friction angle $\left(\varnothing_{\mathrm{w}}\right)$, a rough steel plate was used, replacing only the lower ring by the wall material sample, while the normal load levels were: 50; 40; 30; 20; 10 and $4.4 \mathrm{~N}$. All tests were performed at room temperature $\left(24^{\circ} \mathrm{C}\right)$ and air relative humidity around $67 \%$. 
JENIKE (1964) proposed the flow index $\left(\mathrm{ff}_{\mathrm{c}}\right)$ as a parameter for predicting the performance of the material during discharging from the silo, obtained by the ratio between the consolidation stress $\left(\sigma_{\mathrm{M}}\right)$ and the unconfined stress, fc.

To determine the powder flow function $(\mathrm{FF}), \sigma_{\mathrm{M}}$ versus $\mathrm{f}_{\mathrm{C}}$ values were plotted, which were obtained from Mohr's stress circles and by the interception of the FF curve with the hopper flow factor (ff) line, the unconfined critical stress $\left(\sigma_{\mathrm{CR}}\right)$ was determined to avoid the formation of cohesive arches, which cause discharge obstructions. This methodology is known as the Jenike Flow-No Flow Criteria and defines that if the ratio between $\sigma_{M}$ and $f_{C}$ is greater than $\mathrm{ff}$, there will be flow.

Conical hopper geometry was designed through two different ways. First, the Continuum Mechanics Theory for hopper flow factor proposed by Equations 1 to 6 of ENSTAD (1981) combined with minimum hopper outlet by Jenike's method, equation 7, was applied.

Enstad's equations for flow factor (ff):

$$
\begin{aligned}
& \mathrm{ff}=\frac{\mathrm{Y}(1+\sin \delta)}{2(\mathrm{X}-1) \mathrm{F}(\theta) \cos \theta} \\
& \mathrm{Y}=\frac{(2+2 \cos \alpha)^{2}\left(\alpha^{1+m}\right) \cos \theta+\sin \beta(\sin \alpha)^{1+m}}{(1-\sin \delta)(\sin \alpha)^{2+m}} \\
& X=\frac{2^{m} \sin \delta}{1-\sin \delta}\left[\frac{\sin (\alpha+\beta)+\cos \theta}{\cos \theta}\right] \\
& \alpha=\beta+90-\theta \\
& F(\theta)=\left[\frac{65}{220-\theta}\right]^{\mathrm{m}}\left[\frac{200}{290-\theta}\right]^{1-\mathrm{m}} \\
& \beta=\frac{\emptyset_{\mathrm{w}+\sin ^{-1}\left(\frac{\sin \varphi_{\mathrm{W}}}{\sin \delta}\right)}^{2}}{2}
\end{aligned}
$$

in which:

$\delta$ - effective angle of internal friction $\left(^{\circ}\right)$.

Jenike’s equation for minimum hopper outlet (D):

$\mathrm{D}=\frac{\mathrm{H}(\theta) \sigma_{\mathrm{CR}}}{\gamma}$

in which:

D - minimum hopper outlet (m);

$\mathrm{H}(\theta)$ - constant (dimensionless);

$\sigma_{\mathrm{CR}}$ - unconfined critical stress $(\mathrm{Pa})$, and

$\gamma$ - lower consolidated specific weight $\left(\mathrm{N} / \mathrm{m}^{3}\right)$.

Second, also equations by WALKER (1966) for flow factor (ff) and minimum hopper outlet (D) were tested through equations 8 - 10 and 12, respectively.

Walker's equation for flow factor (ff):

$$
\begin{aligned}
& \mathrm{ff}=\frac{1+\sin \delta}{\Delta} ; \quad \alpha+\emptyset_{\mathrm{w}} \geq 45 \\
& \mathrm{ff}=\frac{1+\sin \delta}{\Delta} \sin 2\left(\alpha+\emptyset_{\mathrm{w}}\right) ; \quad \alpha+\emptyset_{\mathrm{w}}<45^{\circ}
\end{aligned}
$$

in which:

$$
\Delta=2 \sin \delta \sin 2(\alpha+\varepsilon)-\tan \alpha[1-\sin \delta \cos 2(\alpha+\varepsilon)]
$$


$\varepsilon=\frac{1}{2}\left[\emptyset_{\mathrm{w}}+\operatorname{arcsen} \frac{\sin \emptyset \mathrm{w}}{\sin \delta}\right]$

Walker's equation for minimum hopper outlet:

$\mathrm{D}=\frac{2 \sin 2\left(\alpha+\emptyset_{W}\right) \sigma_{\mathrm{CR}}}{\gamma}$

in which:

$\alpha$ - hopper inclination with vertical plane $\left(^{\circ}\right)$,

$\emptyset_{\mathrm{w}}$ - angle of friction wall $\left(^{\circ}\right)$.

Through equation 13 proposed by ENSTAD (1981), it was also possible to determine the minimum hopper inclination with the horizontal plane $\left(\theta_{\mathrm{m}}\right)$ in order to ensure the occurrence of flow.

$$
\theta_{\mathrm{m}}=0,5 \cos ^{-1}\left(\frac{1-\sin \delta}{2 \sin \delta}\right)+\beta
$$

As one of the main difficulties in studying flow in silos is the impossibility of in loco checking due to the opacity of its walls, a reduced semicircular horizontal cross-section model with translucent flat vertical walls of eight mm in thickness was built.

The reduced model was built with walls, flat bottom and hopper made in rough steel plate of nominal thickness of $1.2 \mathrm{~mm}$. In the first phase of the experiment, a flat bottom with concentric outlet of $0.06 \mathrm{~m}$ of opening was used. Next, concentric hopper with horizontal inclination of $70^{\circ}$ and discharge outlet of the same diameter was used (Figure 2).

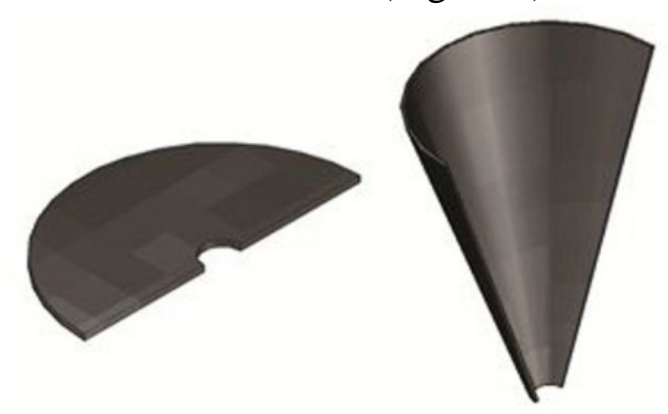

FIGURE 2. Flat bottom and conical hopper used.

The silo structure had dimensions of $1.1 \times 0.45 \mathrm{~m}$ (height $\mathrm{x}$ diameter) representing a silo with H/D ratio equal to 2.4. Figure 3 represents the reduced model of silo using flat bottom and conical hopper with translucent flat vertical walls.
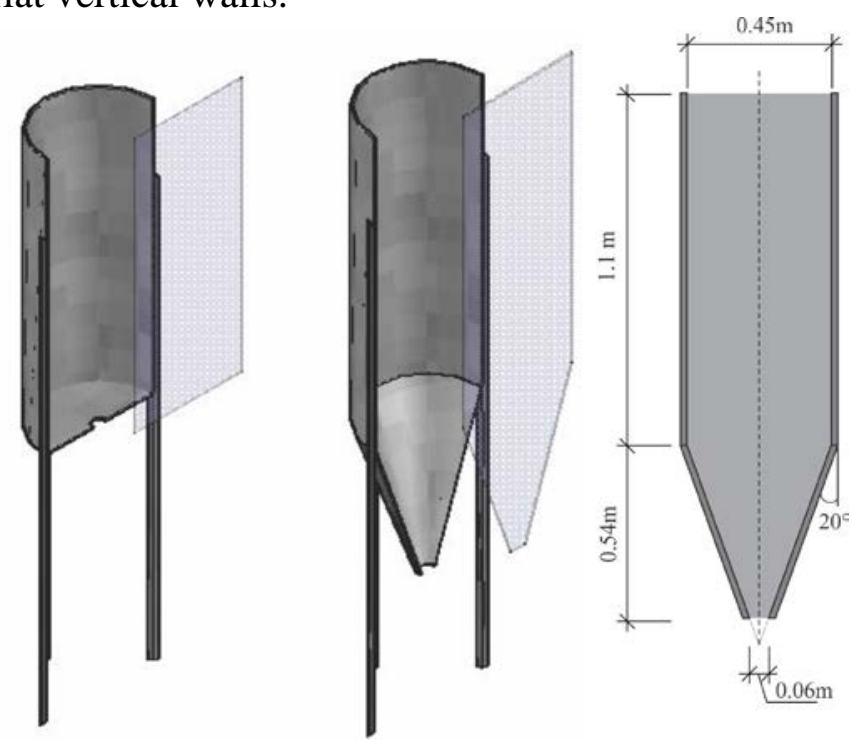

FIGURE 3. Silo with flat bottom and conical hopper. Geometric details. 
In order to obtain images of the flow profile, a high-resolution digital camera was used at a distance of $2.5 \mathrm{~m}$ from the reduced model. The experimental procedure consisted of manually loading the silo in a concentric way and with approximately constant speed, ensuring the least compression as possible due to the impact of the falling product. After a rest period of $30 \mathrm{~min}$, the silo discharging was made by gravity. All assays were performed in four replicates in order to obtain good repeatability of the information collected.

\section{RESULTS AND DISCUSSION}

Figure 4 shows the particle size curves of the powder material analyzed, where it could be observed that ground corn begins to accumulate particles from sieve $2.4 \mathrm{~mm}$, while for the soybean meal, it starts from sieve $1.2 \mathrm{~mm}$, indicating a slight difference in particle size between two powder material in larger sieves. During the tests, moisture contents of 6.6 and $6.5 \%$ for ground corn and soybean meal were recorded, respectively.



FIGURE 4. Grain size curves of the materials.

The flow properties of powders are shown in Table 1, which also shows that the variation between upper and lower limits obtained for the internal friction angle (Ø) of the two powders did not exceed 8\%. Analyzing the absolute value of this property, it could be inferred that soybean meal shows a steeper sliding plane (higher limits for $\varnothing$ ), which means a higher shearing capacity and therefore flow.

TABLE 1. Flow properties of powders.

\begin{tabular}{|c|c|c|c|c|c|c|c|c|c|c|}
\hline \multirow{2}{*}{ Product } & \multicolumn{2}{|c|}{$\gamma$} & \multicolumn{2}{|c|}{$\varnothing$} & \multicolumn{2}{|c|}{$\delta$} & \multicolumn{2}{|c|}{$\varnothing_{w}$} & \multirow{2}{*}{ C } & \multirow{2}{*}{$\mathrm{ff}_{\mathrm{c}}$} \\
\hline & Lower & Upper & Lower & Upper & Lower & Upper & Lower & Upper & & \\
\hline $\begin{array}{c}\text { Ground } \\
\text { corn }\end{array}$ & 7441.4 & 7638.1 & 25.3 & 33.3 & 34.3 & 38.8 & 23.0 & 23.9 & 935.3 & 3.8 \\
\hline $\begin{array}{c}\text { Soybean } \\
\text { meal }\end{array}$ & 6564.2 & 6640.1 & 32.8 & 35.1 & 34.1 & 35.5 & 23.4 & 25.0 & 128.0 & 54.3 \\
\hline
\end{tabular}

$\gamma$ - consolidated specific weight $\left(\mathrm{N} / \mathrm{m}^{3}\right) ; \varnothing$ - internal friction angle $\left(^{\circ}\right) ; \delta$ - effective internal friction angle $\left(^{\circ}\right) ; \emptyset_{w}$ - internal friction angle with rough steel wall $\left(^{\circ}\right)$; $\mathrm{C}$ - average particle cohesion $(\mathrm{Pa})$; $\mathrm{ff}_{\mathrm{C}}$ - Jenike mean flow Index; Lower, Upper - lower and upper limits, respectively.

Another important variable is the particle cohesion (C) where, again, the higher result was obtained for ground corn, indicating that this product may develop high cohesion when stored, which was confirmed by the lower value obtained for the flow index $\left(\mathrm{ff}_{\mathrm{c}}\right.$ ) equal to 3.8 , with forecast of a cohesive-flow type.

The same flow index value $\left(\mathrm{ff}_{\mathrm{c}}\right.$ ) was found by LOPES NETO et al. (2009 a), when analyzing poultry feed samples with fat content of $8.3 \%$; therefore, this value must be taken into account when designing the discharge orifice in order to avoid the formation of cohesive arches. For the soybean meal, the $\mathrm{ff}_{\mathrm{c}}$ index provides a flow with free feature, without difficulty of emptying the silo with lower cohesion (128 Pa) and higher flow index value (54.3). 
Figures $5 \mathrm{~A}$ and B show consolidation stress $\left(\sigma_{\mathrm{M}}\right)$ and unconfined stress (fc) for load series of 100; 70 and $50 \mathrm{~N}$ for ground corn and soybean meal, respectively. Smallest differences between consolidation stress $\left(\sigma_{M}\right)$ and unconfined stress $\left(f_{c}\right)$ for ground corn were found, Figure 5A, which indicates that the change from active to passive state occurs in small intensity, making the occurrence of mass shear difficult and thus impairing flow.
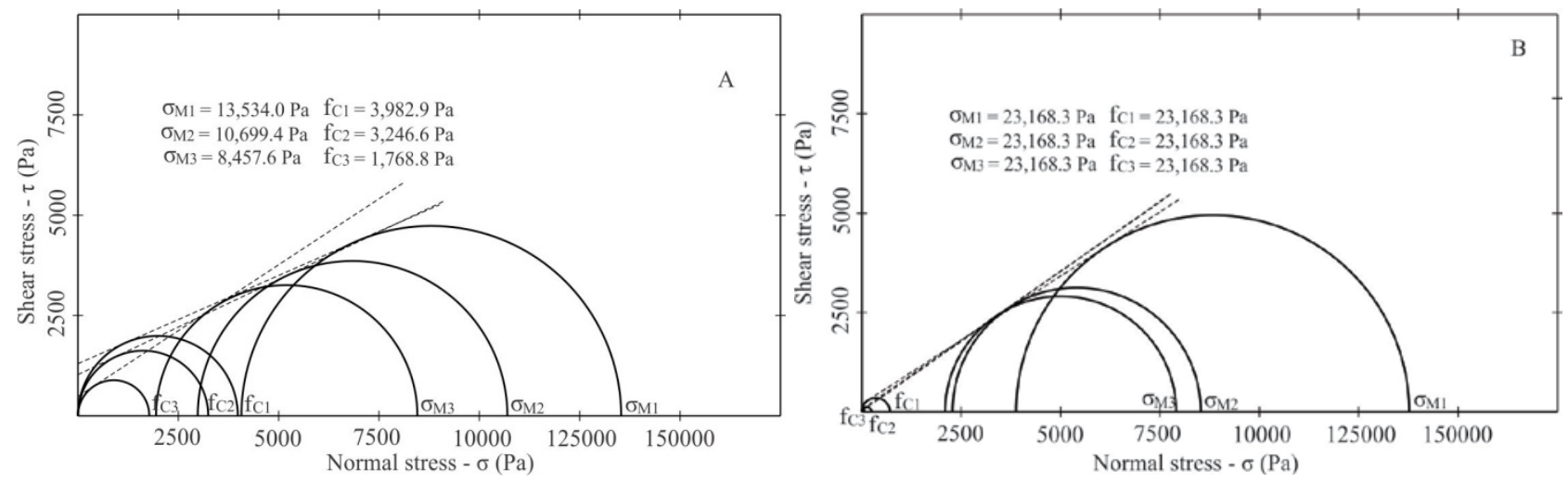

FIGURE 5. Consolidation and unconfined stress. (A) Ground corn, (B) Soybean meal.

It was observed, in Figure $5 \mathrm{~B}$, that the highest $\sigma_{\mathrm{M}}$ values were obtained for soybean meal between 23168.3 and 13307.2 $\mathrm{Pa}$, demonstrating that this product develops greater state of active stress; however, this product showed the lowest fc, indicating the need to achieve lower stress levels for the mass shear to occur.

The relationship between consolidation stress $\left(\sigma_{M}\right)$ and unconfined stress $\left(f_{c}\right)$, called yield locus, means the potential of a product to flow (OPALINSKI et al., 2012) and represents the maximum shear stress that can be supported by the product under a given normal stress, and can be affected by several factors such as humidity, particle size and storage time.

The curves representing the flow function (FF) are shown in Figures 6 and 7, with the greatest slope for ground corn, corresponding to its low flow rate and difficult discharge. Flow function slope of soybean meal is very smooth approaching to major consolidation stress axis $\left(\sigma_{M}\right)$ indicating a very free flow powder without cohesive characteristics. GANESAN et al. (2008) reported that the behavior of the flow function (FF) is a result of the combination between physical and flow properties, environmental conditions and equipment used to handle, store and process these products.

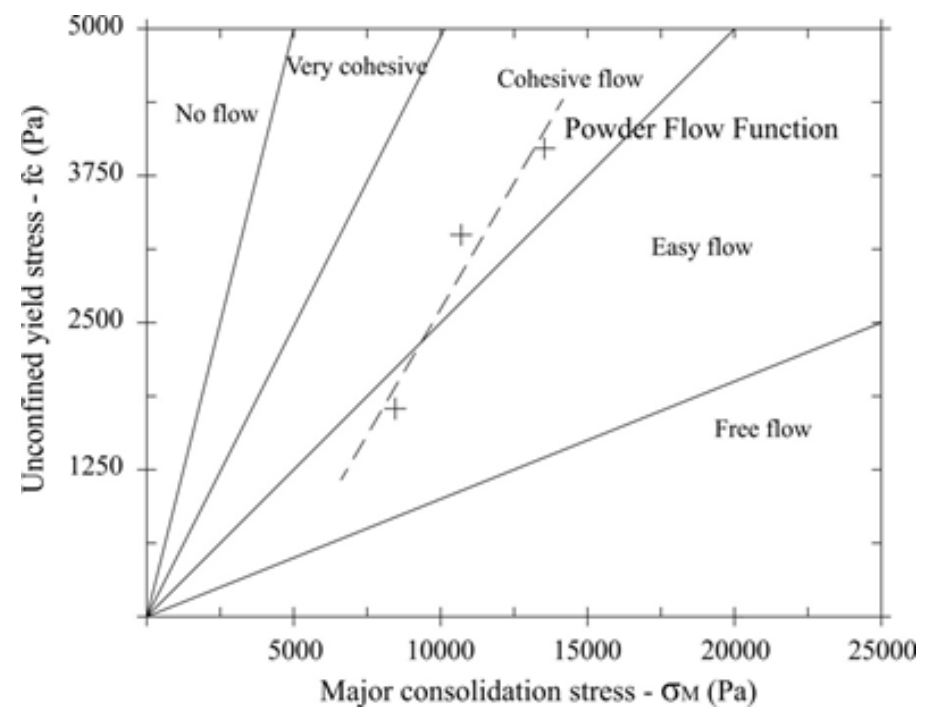

FIGURE 6. Flow function classification for ground corn. 




FIGURE 7. Flow function classification for soybean meal.

It is known that the curve closest to the horizontal axis represents a product of easy flow and, following a counterclockwise direction, such product tends to have higher flow resistance (LOPES NETO et al., 2007), indicating the condition of free flow for soybean meal.

The flow properties of bulk solids have been characterized since JENIKE (1964) in terms of the effective friction angle $\delta$ and the wall friction angle $\varnothing_{w}$. Furthermore the flow function i.e. the dependence of the compression strength fc on the consolidation stress $\sigma_{M}$ is often cited. This relationship considers the influence of a "pre-consolidation'” on the compression strength of a bulk solid (RIPP \& RIPPERGER, 2010)

Table 3 shows the geometric dimensions of the conical hopper, where a maximum inclination in relation to the horizontal plane of $70.2^{\circ}$ for soybean meal and $68.4^{\circ}$ for ground corn can be observed. The highest values of ff were obtained by Walker's equations for both ground corn and soybean meal resulting hopper values 2.2 and 2.75 times lower than obtained by Jenike's equation.

TABLE 3. Design of conical hopper.

\begin{tabular}{cccccc}
\hline \multicolumn{2}{c}{ Ground corn $\left(\theta \mathrm{m}=68.4^{\circ}\right)$} & \multicolumn{2}{c}{ Soybean meal $\left(\theta \mathrm{m}=70.2^{\circ}\right)$} \\
\hline ff Enstad & $\sigma_{\mathrm{CR}}$ & $\mathrm{D}($ Jenike $)$ & ff Enstad & $\sigma_{\mathrm{CR}}$ & $\mathrm{D}($ Jenike $)$ \\
1.5 & 1061 & 0.33 & 1.59 & 632.2 & 0.22 \\
ff Walker & $\sigma_{\mathrm{CR}}$ & $\mathrm{D}$ (Walker) & ff Walker & $\sigma_{\mathrm{CR}}$ & $\mathrm{D}$ (Walker) \\
2.28 & 573.2 & 0.15 & 2.43 & 289.8 & 0.08 \\
\hline
\end{tabular}

MATCHETT et al. (2009) analyzed the formulation of JENIKE (1964) and found discharge orifice values overestimated by $100 \%$ when compared to those from real experiments and concluded that the $\mathrm{f}_{\mathrm{C}}$ value based on the Berry-Jenike model produces discharge orifice dimensions closer to reality.

Figures $8 \mathrm{~A}$ and $\mathrm{B}$ are related to the flow tests in flat-bottomed silo for ground corn and soybean meal, respectively. A manual interference was necessary in order to break the cohesive arch that prevented the material to flow in the beginning of discharge of ground corn. Importantly, the shape of the obstruction did not strictly follow that predicted by the cohesive arch theory, assuming, in this case, a more cylindrical shape. 


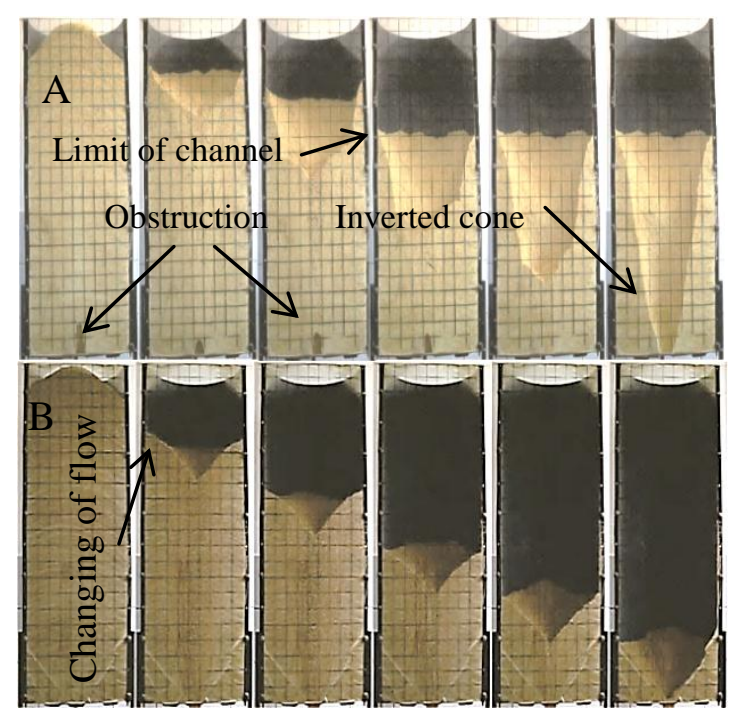

FIGURE 8. Flat-bottomed discharge. (A) Ground corn, (B) Soybean meal.

MATCHETT (2007) concluded that although many cohesive arch theories such as those of JENIKE (1964), ENSTAD (1981) and WALKER (1966) foresee obstruction in the form of circular arches and have good approximation when compared to real situations, this does not mean that the circular arch hypothesis is valid for any discharge situation, because there are no experimental stress information on the product located near the discharge orifice.

Discontinued obstruction, discharging occurred by a flow channel in the form of inverted cone at the time their limits reached H/D ratio $=1.5$ and the whole process took place through successive interruptions, with the formation of arches that interrupted the discharge.

Figure 8B shows that there was an initial formation of the mass flow in the entire mass in descending movement until reaching an H/D ratio of approximately 2 where, thereafter, the funnel flow was predominant, being characterized by one portion of the product still and the other in movement.

This condition is known as plug flow, and according to SADOWSKI \& ROTTER (2011), is characterized when the flow channel limits come to intercept the silo wall yet during the discharge process, and are characteristic of silos classified as slender, which H/D ratio is greater than or equal to 2 .

It is noteworthy that the change in the flow type can be observed by the variation in the shape of the product surface inside the silo, having the convex shape at the beginning of the discharge, leveling at the time when there is a change in the flow pattern and ending with the shape of an inverted cone with angle of approximately $54^{\circ}$.

Figures 9A and 9 show sequential images of the discharge of ground corn and soybean meal, respectively, in silo with conical hopper. Figure 9A shows that ground corn was discharged even in a disorderly, poorly structured way and of difficult definition, confirming the prediction of cohesive flow by the flow index $\left(\mathrm{ff}_{\mathrm{c}}\right)$ of JENIKE (1964).

It was possible to visually observe that the flow began with the formation of a vertical and central flow channel, spreading upwardly until it reached the upper surface of the stored mass. It was also observed that the discharge was carried out through successive attempts to form the pipping effect and frequent side walls collapse whenever reaching an average height of $45 \mathrm{~cm}$. 




FIGURE 9. Discharge with conical hopper. (A) Ground corn, (B) Soybean meal.

Figure 9B shows the mass flow for all replicates. The mass flow occurred up to H/D ratio = 1.5, when there was a faster flow channel with peripheral limits reaching vertical walls at an H/D ratio $=0.9$. The mass flow has certain advantages over the funnel flow, especially when one desires to avoid fluctuations in the discharge flow and reduce the segregation effects, enhancing homogeneity; however, it has some disadvantages such as the occurrence of high stresses in the transition zone and higher superficial wear of walls due to constant friction (CALIL JUNIOR \& CHEUNG, 2007).

Despite variations in the mass flow shown in Figures 9A and 9B, the conical hopper inclination was sufficient to promote complete silo emptying, validating equations proposed by ENSTAD (1981) for this purpose.

For the discharge outlet, the methodology of Jenike seemed to be conservative when recommending orifices with dimensions 5.5 to 3.3 times higher for ground corn and soybean meal, respectively, than those used in this study to obtain flow. The results of minimum hopper outlet proposed by Walker's equations showed more approached been 2.5 and 1.4 times higher than experimental hopper outlet.

\section{CONCLUSIONS}

It could be concluded that the index flow methodology $\left(\mathrm{ff}_{\mathrm{c}}\right)$ of JENIKE (1964) accurately predicted how the flow of the three products would occur in both discharging situations.

The hopper geometry design theory proposed by ENSTAD (1981) seemed to be adequate to recommend sufficient inclination to ensure the occurrence of mass flow and the complete discharge of the products analyzed.

The theoretical values for the discharge outlet obtained through Jenike's equation showed great variation when compared to the experimental orifice diameter used to obtain discharge flow. A lower difference was obtained when Walker's equations were applied. However, all two theories applied for design of hopper outlet need for adjustment for represent real opening orifice to be used in powder flow discharge.

The semicircular shape reduced model seemed to be suitable for viewing the flow profile and variations occurring during the flow.

\section{ACKNOWLEDGMENTS}

The authors would like to thank the Research Group on Silos (SILOS) and the Study Group on Livestock and Rural Constructions (GCAMB) - Federal University of Campina Grande, Brazil, for their support for this research. 


\section{REFERENCES}

BMHB - British Materials Handling Board. Draft code of practice for the design of silos, bins, bunkers and hoppers. Berkshire: BMHB, 1985. 143 p.

CALIL JUNIOR, C.; CHEUNG, A. B. Silos: pressões, fluxo, recomendações para o projeto e exemplos de cálculo. São Carlos: EESC, 2007. 232 p.

CANNAVACCIUOLO, A.; BARLLETA, D.; DONSİ, G.; FERRARI, G.; POLETTO, M. Archfree flow in aerated silo discharge of cohesive powders. Powder Technology, New York, v.191, p.272-279, 2009.

ENSTAD, G. G. A novel theory on the arching and doming in mass flow hoppers. Bergen: The Michelsen Institute, 1981. 172 p.

GANESAN, V.; ROSENTRATER, K. A.; MUTHUKUMARAPPANA, K. Flowability and handling characteristics of bulk solids and powders - a review with implications for DDGS. Biosystems Engineering, London, v.101, p.425-435, 2008.

JENIKE, A. W. Storage and flow of silos. Salt Lake City: University of Utah, 1964. 89 p. (Bulletin, 123).

JULIANO, P.; MUHUNTHAN, B.; CÁNOVAS, G. V. B. Flow and shear descriptors of preconsolidated food powders. Journal of Food Engineering, Essex, v.72, p.157-166, 2006.

LOPES NETO, J. P.; NASCIMENTO, J. W. B. do; SILVA, V. R.; Lopes, F. F. M. Propriedade de fluxo e característica de escoabilidade de rações avícolas para dimensionamento de silos. Revista Ciência e Agrotecnologia, Lavras, v.31, n.3, p.851-859, 2007.

LOPES NETO, J. P.; NASCIMENTO, J. W. B.; SILVA, V. R. Efeito do tempo de armazenagem de rações avícolas no dimensionamento de silos. Engenharia Agrícola, Jaboticabal, v.29, p.518-527, 2009a.

LOPES NETO, J. P.; SILVA, V. R.; NASCIMENTO, J.P. Propriedades de fluxo de produtos pulverulentos alimentícios. Revista Brasileira de Engenharia Agrícola e Ambiental, Campina Grande, v.13, p.639-644, 2009b.

MATCHETT, A. J. The shape of the cohesive arch in hoppers and silos - Some theoretical considerations. Powder Technology, New York, v.171, p.133-145, 2007.

MATCHETT, A. J.; O’NEILL, J.; SHAW, A. P. Stresses in bulk solids in wedge hoppers: A flexible formulation of the co-ordinate specific, Lame-Maxwell equations for circular arc, principal stress systems. Powder Technology, New York, v.194, p.166-180, 2009.

OPALINSKI, I.; CHUTKOWSKI, M.; STASIAK, M. Characterizing moist food-powder flowability using a Jenike shear-tester. Journal of Food Engineering, Essex, v.108, p.51-58, 2012.

PALMA, G.; CALIL JUNIOR, C. Pressões e fluxo em silos esbeltos (H/D $\geq 1.5)$. Cadernos de Engenharia de Estruturas, São Carlos, v.10, n.42, p.129-150, 2008.

RIPP, M.; RIPPERGER, S. Influence of temperature on the flow properties of bulk solids. Chemical Engineering Science, New York, v.65, p.4007-4013, 2010.

SADOWSKI, A. J.; ROTTER, J. M. Steel silos with different aspect ratios: II - behavior under eccentric discharge. Journal of Constructional Steel Research, London, v.67, p.1545-1553, 2011.

SCHULZE, D. Powders and bulk solids. Behavior, characterization, storage and flow. Berlin: Springer, 2008. 517 p.

WALKER, D. M. An approximate theory for pressures and arching in hoppers. Chemical Engineering Science, New York, v.21, p.975-997, 1966. 